\title{
Impact of proximal cytoplasmic droplets on quality traits and in-vitro embryo production efficiency of cryopreserved bull spermatozoa
}

\author{
Janaina T Carreira', Gisele Z Mingoti ${ }^{2}$, Lucia H Rodrigues ${ }^{3}$, Carlos Silva ${ }^{3}$, Silvia HV Perri ${ }^{2}$ and Marion B Koivisto ${ }^{{ }^{*}}$
}

\begin{abstract}
Background: Proximal cytoplasmic droplets (PCDs), a remnant of germ cell cytoplasm, are common non-specific morphological defects in bovine semen. This study evaluated the effect of higher percentages of PCDs on the quality of frozen-thawed bovine semen, embryo production and early embryo development.
\end{abstract}

Methods: Three ejaculates from each of five (group 1: PCD $\leq 1 \%$, control) and eight adult Bos indicus bulls (group 2: $P C D \geq 24 \%)$ were analysed. Semen samples were examined for: post-thaw motility, vigour of movement, concentration, sperm morphology, slow thermoresistance test (STT), membrane integrity, acrosome status, mitochondrial function using fluorescent probes association (FITC-PSA, PI and JC-1) and sperm chromatin integrity using acridine orange assay. Two bulls from group 2, with 28.5\% and 48.5\% PCD, respectively, and three bulls from the control group, each with 0\% PCD, were selected for IVF (in vitro fertilisation).

Results: Semen analyses revealed a significant correlation $(P<0.01)$ between increased rates of PCD and sperm quality traits. Nevertheless, no differences were observed in sperm motility and vigour either before or after the STT or in the percentage of intact acrosomes (analysed by differential interference contrast microscopy (DIC) after ST), but membrane integrity, acrosome status (evaluated with FITC-PSA staining method after thawing) and mitochondrial function were reduced, when compared with group $1(P<0.05)$. The higher incidence of PCD was positively correlated to chromatin damage, especially after three hours of incubation at $37^{\circ} \mathrm{C}$. IVF showed similar results for bull C2 (group 1, control) and bull P2 (group 2, group with higher PCDs).

Conclusion: Higher PCD levels influenced spermatozoa quality traits. IVF and embryo development data showed that cleavage, blastocyst formation and blastocyst hatching may have been influenced by the interaction of morphology traits and individual bull effects.

Keywords: sperm morphology, proximal cytoplasmic droplets, IVF, fluorescent probes

\section{Background}

In the last decade, major advances have been made in the understanding of the biochemical and molecular mechanisms that determine the production of functionally competent spermatozoa [1]. Disturbed sperm-oocyte interaction is the principal cause of low IVF rates in humans and seems to be more associated with sperm defects than with oocyte defects because sperm can penetrate the zona pellucida of oocytes at any stage of

\footnotetext{
* Correspondence: koivisto@fmva.unesp.br

'Univ Estadual Paulista (UNESP), FMVA, Faculty of Veterinary Medicine,

Department of Clinics, Surgery and Animal Reproduction, Araçatuba, Brazil Full list of author information is available at the end of the article
}

maturity and quality. Thus, the proportion of zona pellucida-bound spermatozoa with normal or abnormal morphology is strongly related to IVF success rates [2].

Proximal cytoplasmic droplets (PCDs) can be identified as a regularly shaped remnants of cytoplasm under the plasma membrane in the neck region of the spermatozoa [3]. In a recent study on spermatozoal quality at spermiation in humans, two different kinds of proximal cytoplasmic droplets were described: proximal droplets that reflect epididymal and accessory sex gland alteration and spermatozoa with notable residual cytoplasm (not a cytoplasmatic droplet), indicating an immature cell with improper or incomplete spermiogenesis $[4,5]$. 
High percentages of PCDs can be found in the semen of prepubertal bulls, while in mature bulls, high levels of sperm with PCDs are considered a sign of abnormality in spermiogenesis or epididymal sperm maturation $[3,6,7]$.

To have fertilising ability, spermatozoa must acquire a combination of features, such as intact plasma membranes, acrosome integrity, and high mitochondrial membrane potential for the production of adenosine triphosphate (ATP)-generating energy for flagellar beat and motility [8]. Chromatin integrity is another important factor because DNA fragmentation impairs fertility [9]. Combining the results of various sperm function tests improves the reliability of fertility estimation. Current research therefore focuses on identifying a range of tests to assess as many meaningful sperm attributes as possible and doing so easily and at a reasonable cost. Moreover, staining protocols are available for an increasing range of sperm characteristics, including viability, capacitation and acrosome status, mitochondrial activity and chromatin integrity [10]. The objective of this study was to investigate whether a higher percentage of spermatozoa with proximal cytoplasmic droplets could affect the quality and fertilising ability of frozenthawed semen of Bos indicus (Nellore breed) bulls, using routine laboratory sperm assays, plasma membrane, acrosome and mitochondrial status, chromatin integrity and IVF.

\section{Methods}

\section{Animal selection}

A total of 13 mature Bos indicus bulls were selected from an artificial insemination centre located in the southeast of Brazil ( $\left.21^{\circ} 04^{\prime} 52^{\prime \prime} \mathrm{S}, 48^{\circ} 02^{\prime} 24^{\prime \prime} \mathrm{W}\right)$; five of the bulls presented normal sperm patterns, with $\leq 1 \%$ spermatozoa with proximal cytoplasmic droplets (PCDs) and $\leq 14 \%$ total sperm defects (group 1, control, range 4 to 13 years), and eight bulls showed increased levels of PCDs $(\geq 24 \%)$ and of total defects $(\leq 48 \%)$ (group 2, range 5 to 15 years). Three ejaculates were collected from each bull using an artificial vagina and were cryopreserved (TRIS-egg yolk extender, 7\% glycerol in 250 $\mu$ l French mini-straws) for further evaluation, within a regular twice-a-week collection schedule. The bulls were kept on their native pasture (Cynodon plectostachyus) and were given dietary supplementation to optimise their energy balance.

\section{Semen evaluation}

\section{Sperm motility, vigour and concentration}

Immediately after thawing $\left(35^{\circ} \mathrm{C}\right.$ for $\left.20 \mathrm{sec}\right)$, the percentage of progressively motile sperm and their vigour (status of sperm motility), scored on a scale from 0 (without movement) to 5 (fast progressive movement), were determined by subjective estimation using phase contrast microscopy $(200 \times)$.

Furthermore, sperm concentration $\left(\times 10^{6}\right)$ was determined under phase-contrast optics $(200 \times)$ using a haemocytometer Neubauer chamber.

\section{Morphologic abnormalities}

Sperm alterations were classified, according to Blom [11] and Barth and Oko [12], into major defects (acrosome defects, proximal droplets, abnormal loose heads, abnormal contours, abnormal midpieces, nuclear vacuoles, double forms and dag defects) and minor defects (small normal heads, normal loose heads, abaxial implantation, coiled tails and distal droplets). A total of 200 cells (\%, DIC microscopy, oil immersion, 1000×, Olympus BX61), recording one abnormality per cell, were examined per sample.

\section{Slow thermoresistance test (STT)}

After thawing, the samples were transferred to a glass tube, and motility, vigour and DNA integrity were assessed. Subsequently, the semen was incubated for 3 hours at $37^{\circ} \mathrm{C}$; after incubation, motility, vigour and DNA integrity were assessed again, as was the percentage of intact acrosomes (PIA) (\%, DIC microscopy, oil immersion, 1000×, Olympus BX61) [13].

\section{DNA integrity}

Chromatin integrity was assessed using the acridine orange (AO) technique described by Tejada et al. [14] and modified by Unanian [15], who washed the samples with distilled water. Acridine orange is a DNA metachromatic stain that permits the detection of DNA fragmentation by colour differences (green for intact chromatin and yellow to red for damaged DNA).

The staining solution was prepared from a $10-\mathrm{ml}$ stock of AO (1 g of AO, Sigma, St. Louis, MO, USA, diluted in $1000 \mathrm{ml}$ of distilled water, and stored at $4^{\circ} \mathrm{C}$ in the dark), $40 \mathrm{ml}$ of $0.1 \mathrm{M}$ citric acid anhydrous solution, $2.5 \mathrm{ml}$ of $0.3 \mathrm{M} \mathrm{Na}_{2} \mathrm{HPO}_{4}$ solution and $\mathrm{pH} 2.5$.

Semen samples $(100 \mu \mathrm{l})$ were centrifuged with $100 \mu \mathrm{l}$ of distilled water at $300 \mathrm{~g}$ for 5 minutes to remove the egg-yolk extender and to promote damage to the plasma membranes. Semen pellets were washed twice, and two slides (one was stored for security) were prepared and dried at room temperature for $60 \mathrm{~min}$. Dried smears were submersed in Carnoy's solution (three parts methanol to one part acetic acid). After $12 \mathrm{~h}$ of fixation, the slides were stained for five minutes with $3 \mathrm{ml}$ of acridine orange solution (10 ml acridine orange, $1 \mu \mathrm{g} /$ $\mathrm{ml} ; 40 \mathrm{ml}$ citric acid $0.1 \mathrm{M} ; 2.5 \mathrm{ml}$ sodium phosphate $0.3 \mathrm{M}, \mathrm{pH} 2.5$ ) and protected from light exposure. The slides were analysed under an epifluorescence microscope (Olympus BX61 - Tokyo, Japan - excitation 460$570 \mathrm{~nm}$ and emission 460-610 nm; 400x). For each smear, 400 cells were classified as follows: cells emitting 
green fluorescence were considered to have intact chromatin, and cells emitting red, orange or red/orange fluorescence, distributed in a regular or irregular pattern within the sperm head, were classified as spermatozoa with partial or total chromatin denaturation [16]. A DNA integrity assay was repeated at the end of the STT $\left(37^{\circ} \mathrm{C} / 3 \mathrm{~h}\right)$.

\section{Plasma membrane integrity, acrosome integrity and mitochondrial potential}

Plasma membrane, acrosomal integrity and mitochondrial function were evaluated using the techniques described by Celeghini et al. [17] and Gonçalves et al. [18], which involve the combination of propidium iodide (PI, Sigma, St. Louis, MO, USA), fluorescein-conjugated Pissum sativum agglutinin (FITC-PSA, Sigma, MO, USA) and JC-1 (Sigma, St. Louis, MO, USA).

The solutions were prepared according to Celeghini et al. [17]; briefly, a $25 \mathrm{mg} / \mathrm{ml}$ PI stock solution was prepared in dimethyl sulphoxide (DMSO) and stored at $-20^{\circ} \mathrm{C}$, the working solution was diluted to $0.2 \mathrm{mg} \mathrm{PI} / \mathrm{ml}$ Dulbecco's phosphate buffer (DPBS) $\left(-20^{\circ} \mathrm{C}\right.$, in the dark).

The FITC-PSA working solution was prepared adding $100 \mu \mathrm{g}$ FITC-PSA to $1 \mathrm{ml}$ of DPBS with $10 \%$ sodium azide solution (10\%) and kept at $4^{\circ} \mathrm{C}$ in the dark. For the JC-1 stock solution $5 \mathrm{mg}$ of JC-1 was mixed to $1 \mathrm{ml}$ of DMSO; for staining, $200 \mu \mathrm{l}$ of stock solution was added to $800 \mu \mathrm{l}$ of DMSO in a final concentration of 0.1 $\mathrm{mg} / \mathrm{ml}(153 \mu \mathrm{M})$ of $\mathrm{JC} 1$ and stored at $-20^{\circ} \mathrm{C}$ in the dark.

Thawed semen samples $(250 \mu \mathrm{L})$ were transferred to $500 \mu \mathrm{l}$ of modified Tyrode's albumin lactate pyruvate (TALP; [19]) and centrifuged at $300 \mathrm{~g}$ for 5 minutes. The sediment was resuspended and centrifuged twice in $250 \mu \mathrm{l}$ of TALP. A $30-\mu \mathrm{l}$ aliquot of diluted semen in TALP medium $\left(25 \times 10^{6} \mathrm{sptz} / \mathrm{ml}\right)$ was transferred to a warmed microtube containing $2 \mu \mathrm{l}$ of PI $(0.2 \mathrm{mg} / \mathrm{ml})$, $1.6 \mu \mathrm{l}$ of JC- $1(0.5 \mathrm{mg} / \mathrm{ml})$ and $10 \mu \mathrm{l}$ of FITC-PSA $(100$ $\mu \mathrm{g} / \mathrm{ml})$. The samples were incubated at $37^{\circ} \mathrm{C}$ for eight minutes and protected from light exposure. An 8- $\mu$ l sample of the stained spermatozoa suspension was placed on a slide, coverslipped and immediately analysed under an epifluorescence microscope (Olympus BX61 Tokyo, Japan, 400×) with an excitation filter at 460-570 $\mathrm{nm}$ and an emission filter at 460-610 nm. Two hundred cells were examined and classified based on the fluorescence emitted from each probe. Propidium iodide-positive cells (damaged plasma membrane) showed a redstained nucleus, FITC-PSA-positive cells (damaged acrosome) presented a yellow-green acrosome region, JC-1 - positive cells (high mitochondrial potential) showed a bright red-orange colour in the mid-piece region, and JC-1-negative cells (low mitochondrial potential) presented a bright green colour in the mid-piece region.

\section{Oocyte collection and maturation}

Bovine ovaries were obtained in a local abattoir and transported to the laboratory. Intact cumulus-oocyte complexes were aspirated from antral follicles $(2-8 \mathrm{~mm}$ in diameter). Oocytes with at least four layers of cumulus cells were selected for the experiments. Oocytes (20 oocytes per droplet) were washed and cultured in $100-\mu \mathrm{l}$ droplets of in vitro maturation (IVM) medium, which consisted of TCM-199 (Gibco BRL, NY, USA) supplemented with $10 \%(\mathrm{v} / \mathrm{v})$ foetal calf serum (FCS; Gibco BRL, NY, USA), $0.2 \mathrm{mM}$ sodium pyruvate, $25 \mathrm{mM}$ sodium bicarbonate, $50 \mu \mathrm{g} / \mathrm{ml}$ amikacin, $0.5 \mu \mathrm{g} / \mathrm{ml} \mathrm{FSH}$ (Pluset $^{\circledR}$; HertapeCalier, MG, Brazil), $100 \mathrm{IU} / \mathrm{ml}$ hCG (Profasi ${ }^{\circledR}$; Serono, SP, Brazil) and $1.0 \mu \mathrm{g} / \mathrm{ml}$ estradiol$17 \beta$. Culture was carried out for $24 \mathrm{~h}$ at $38.5^{\circ} \mathrm{C}$ under an atmosphere of $5 \% \mathrm{CO}_{2}$, in air with maximum humidity [20-22].

\section{Sperm preparation and in vitro fertilisation (IVF)}

Five bulls were selected for IVF: three from group 1, all of them showing 0\% PCDs in semen, and two from group 2, with $28.5 \%$ and $40.5 \%$ spermatozoa with PCDs. The IVF procedure was repeated six times, and the semen of all five bulls was used in all of the iterations. For IVF, frozen-thawed semen was prepared by washing twice at $300 \mathrm{~g}$ for $5 \mathrm{~min}$ in pre-warmed TALP at $38.5^{\circ}$ C. The washed semen was added to the fertilisation drops at a final concentration of $2 \times 10^{6}$ sperm cells $/ \mathrm{ml}$ of IVF medium, which consisted of TALP supplemented with $0.2 \mathrm{mM} \mathrm{Na}$-pyruvate, $6 \mathrm{mg} / \mathrm{ml}$ fatty acid-free bovine serum albumin (BSA), $25 \mathrm{mM}$ sodium bicarbonate, $13 \mathrm{mM}$ Na-lactate, $50 \mu \mathrm{g} / \mathrm{ml}$ amikacin, $4 \mu \mathrm{l} / \mathrm{ml}$ PHE solution (1 $\mathrm{mM}$ hypotaurine, $2 \mathrm{mM}$ penicillamine and $250 \mu \mathrm{M}$ epinephrine) and $10 \mu \mathrm{g}$ heparin. Oocytes and sperm were co-incubated at a concentration of $5 \times$ $10^{3}$ sperm cells/oocyte (20 oocytes per $100-\mu$ l droplet and $100 \times 10^{3}$ sperm cells $/ 4 \mu \mathrm{l}$ medium) for $18 \mathrm{~h}$ under the same temperature and atmospheric conditions used for IVM [20-22].

\section{Embryo culture}

Following fertilisation, the presumptive zygotes were transferred to in vitro culture medium (IVC) consisting of modified oviductal fluid [23] supplemented with 50 $\mu \mathrm{g} / \mathrm{ml}$ amikacin, $5 \mathrm{mg} / \mathrm{ml}$ fraction fatty acid-free BSA and $2.5 \%$ FCS. Zygotes were incubated under mineral oil up to $48 \mathrm{~h}$ post-insemination (hpi) for the assessment of cleavage rates under stereoscopic microscopy $(40 \times)$, when two- and four-cell embryos were counted. Blastocyst development rates were recorded at day 7 (168 hpi), and hatched blastocysts were counted at day 8 (192 hpi) IVC. The temperature and gas atmosphere were the same as used for IVM and IVF [20-22]. 


\section{Statistical analyses}

The null hypothesis $\left(\mathrm{H}_{0}\right)$ was that there were no differences between bulls with high and low levels of PCD regarding sperm quality traits and embryo production efficiency. Statistical analyses were performed using the Statistical Analysis System software (release 9.2. SAS Institute Inc., Cary, NC, USA, 2008). Data (except vigour) were transformed in $\arcsin \sqrt{\%}$ to obtain a normal distribution. Concentration, PIA, membrane integrity, acrosome integrity, mitochondrial potential and IVF results were examined using two-way ANOVA (bull $x$ group); for the STT, results (motility, vigour and DNA integrity) were tested by MANOVA (bull $\times$ group $\times$ incubation time). The means were compared using least square methods. The correlation coefficient $(r)$ and determination factor $\left(r^{2}\right)$ were calculated for motility, vigour, membrane and acrosome integrity, mitochondrial potential and DNA integrity. The data were presented as means \pm SDs and were considered statistically significant when $\mathrm{P}<0.05$ [24].

\section{Results}

The post-thaw semen quality of the five bulls from group 1 and eight bulls of group 2 are summarised in Tables 1 and 2. No statistical differences were seen between the groups for sperm concentration and the percentage of minor morphological defects; nevertheless, as expected, total major defects and the percentage of PCDs were higher for group 2 - PCD $(\mathrm{P}<0.05)$ (Table $1)$. The total morphological defects percentages can be mainly attributed to the higher PCD levels as seen by the determination factor (0.93) and the regression equation (total morphological defects $=11.69+1.41 \mathrm{PCD}$ ).

The percentage of progressively motile spermatozoa and vigour before and after STT, as well as the percentage of spermatozoa with intact acrosomes analysed by PIA method (PIA), were not different between groups 1 and 2. However, when the correlation coefficient and determination factors were calculated for these traits, significant values $(P<0.01)$ were found (Table 3$)$.

Table 1 Summary of semen traits (mean \pm SD) for group $1(n=5)$ and group $2(n=8)$

\begin{tabular}{lcc}
\hline \hline & $\begin{array}{c}\text { Group 1 } \\
\text { (Control) }\end{array}$ & $\begin{array}{c}\text { Group 2 } \\
\text { (PCD) }\end{array}$ \\
\hline $\begin{array}{l}\text { Sperm concentration (million/ } \\
\text { ml) }\end{array}$ & $29.0 \pm 4.1^{a}$ & $31.8 \pm 8.0^{a}$ \\
Major sperm defects (\%) & $4.7 \pm 2.6^{\mathrm{a}}$ & $38.6 \pm 10.8^{\mathrm{b}}$ \\
Minor sperm defects (\%) & $5.4 \pm 2.2^{\mathrm{a}}$ & $9.2 \pm 6.1^{\mathrm{a}}$ \\
Total sperm defects (\%) & $10.1 \pm 3.4^{\mathrm{a}}$ & $47.9 \pm 13.3^{\mathrm{b}}$ \\
PCD (\%) & $0.5 \pm 0.6^{\mathrm{a}}$ & $24.6 \pm 11.3^{\mathrm{b}}$ \\
\hline
\end{tabular}

Means with different superscripts in the same line differ significantly $(P<$ $0.05)$.
The semen samples from group 2 (PCD) showed higher levels $(P<0.05)$ of spermatozoa with simultaneously damaged acrosomes, damaged membranes and low mitochondrial potential; furthermore, group 1 (control) had a higher percentage $(\mathrm{P}<0.05)$ of cells with positive characteristics, such as intact membranes, intact acrosomes and high mitochondrial potential (Table 4). With regard to damaged acrosomes, plasma membranes and low mitochondrial potential, the PCD group presented higher values than group $1(\mathrm{P}<0.05)$.

No significant differences were found between group 1 and group 2 regarding sperm chromatin status before and after STT (Table 2). Nevertheless, the correlation between PCDs and DNA damage was significant and was even higher after STT (Table 3). Regarding in vitro fertilisation results for semen samples from group 1 (n $=3)$ and group $2(n=2)$, the rates of cleavage, blastocyst formation and hatched blastocysts showed no significant differences (Table 5). However, the percentages of hatched blastocysts differed between bulls C1, C3 and P1 $(18.0 \% \pm 79.7,16.5 \% \pm 7.9$, and $16.1 \% \pm 11.1$, respectively) at one extreme and bulls C2 and P2 $(2.5 \% \pm 3.6$ and $2.7 \% \pm 3.5$, respectively) at the other (Table 6 ).

\section{Discussion}

Previous studies have related spermatozoa with increased percentages of PCDs to lower motility in humans [25]. A similar connection was found in the present study, as seen by the significant $(\mathrm{P}<0.001)$ negative correlation between motility and PCDs. In young beef bulls, zero to six weeks after puberty, the percentage of progressively motile spermatozoa increased rapidly, while the percentage of spermatozoa with proximal cytoplasmic droplets was correspondingly dramatically reduced [26]. High percentages of ejaculated spermatozoa with retained cytoplasmic droplets are associated with infertility in adult bulls $[3,8,9]$. A recent review indicated that elimination of the droplets during ejaculation may be prognostic for fertility, while their retention may indicate sub- or infertility [27].

Morphologically abnormal spermatozoa are more susceptible to oxidative stress. The production of reactive oxygen species (ROS) by spermatozoa with PCDs can induce oxidative stress [28], resulting in cellular dysfunction by a number of mechanisms, among them membrane lipid peroxidation [1]. Lipidic peroxidation was observed in situ in human [29] and bovine [28] spermatozoa midpieces, incorporating the mitochondria and any retained excess residual cytoplasm $[29,30]$. The impact of the cryopreservation process on membranes and mitochondria has been intensely studied [31-36]. However, there are few studies indicating that semen with specific morphological alterations would be more sensitive to injuries on these compartments $[7,29,36]$. 
Table 2 Mean \pm SD percentage of progressively motile spermatozoa, sperm vigour, percentage of spermatozoa with intact acrosomes and DNA damage in semen samples with low (group 1, control) and increased percentages of proximal cytoplasmic droplets (PCD, group 2) before (Oh) and after $3 \mathrm{~h}$ of incubation at $37^{\circ} \mathrm{C}$

\begin{tabular}{cccccccc} 
& \multicolumn{2}{c}{ Motility (\%) } & \multicolumn{2}{c}{ Vigour (0-5) } & \multicolumn{2}{c}{ PIA (\%) } & \multicolumn{2}{c}{ DNA damage (\%) } \\
\cline { 2 - 8 } & Oh & 3h & Oh & 3h & 3h & 0h & 3h \\
\hline Group 1 $(\mathbf{n = 5 )}$ & $45.3 \pm 6.7^{\mathrm{a}}$ & $35.0 \pm 8.2^{\mathrm{b}}$ & $4.5 \pm 0.1^{\mathrm{a}}$ & $3.8 \pm 0.7^{\mathrm{b}}$ & $54.6 \pm 6.9$ & $0,5 \pm 0,3$ & $1,0 \pm 0,4$ \\
Group 2 $(\mathbf{n}=\mathbf{8})$ & $40.8 \pm 17.1^{\mathrm{a}}$ & $25.4 \pm 13.3^{\mathrm{b}}$ & $4.0 \pm 1.3^{\mathrm{a}}$ & $3.1 \pm 1.4^{\mathrm{b}}$ & $42.7 \pm 17.5$ & $0,7 \pm 0,4$ & $1,4 \pm 1,3$ \\
\hline
\end{tabular}

Means with different superscripts in the same line differ significantly $(P<0.05)$.

Considering these data, the high percentages of spermatozoa with damaged plasma membranes and acrosomes and with low mitochondrial potential, as observed in group 2 for semen samples with high proportions of PCDs, may have been due to higher production of ROS, resulting in oxidative damage. Although differences were observed in the results obtained for acrosome integrity as analysed using the PIA and triple staining techniques, this discrepancy was due to different methodologies; PIA evaluates the percentage of detached acrosomes after STT $\left(37^{\circ} \mathrm{C} / 3 \mathrm{~h}\right)$ [13], while the FITC-PSA fluorescent probe binds the glycoconjugates and thus labels the acrosome content and indirectly determines acrosome integrity [37]. Nevertheless, the correlation in the results indicates that PCDs have an important effect on acrosome integrity, regardless of the evaluation method.

Semen DNA integrity did not differ between group 1 and group 2; however, the results indicated a higher correlation between the percentage of spermatozoa with PCDs and stable DNA, in particular after STT,

Table 3 Regression, correlation coefficients and levels of significance for proximal cytoplasmic droplets (PCD) versus sperm quality traits

\begin{tabular}{lccccc}
\hline \hline & \multicolumn{5}{c}{$Y=\mathbf{a}+\mathbf{b P C D}$} \\
\cline { 2 - 6 } & $\mathbf{a}$ & $\mathbf{b}$ & $\mathbf{r}^{2}$ & $\mathbf{r}$ & $\mathbf{P}$ \\
\hline Motility 0h & 49.65 & -0.47 & 0.24 & -0.50 & 0.0012 \\
Motility 3h & 36.71 & -0.50 & 0.35 & -0.59 & $<0.0001$ \\
Vigour 0h & 4.83 & -0.04 & 0.33 & -0.58 & $<0.0001$ \\
Vigour 3h & 4.11 & -0.05 & 0.34 & -0.58 & $<0.0001$ \\
PIA 3h & 58.15 & -0.71 & 0.46 & -0.68 & $<0.0001$ \\
Damaged DNA 0h & 0.47 & 0.02 & 0.16 & 0.40 & 0.0103 \\
Damaged DNA 3h & 0.28 & 0.05 & 0.26 & 0.51 & 0.0006 \\
IIH & 27.71 & -0.37 & 0.59 & -0.77 & $<0.0001$ \\
DDL & 51.60 & 0.44 & 0.30 & 0.54 & 0.0002 \\
Damaged acrosome & 62.41 & 0.27 & 0.22 & 0.47 & 0.0020 \\
Damaged sperm membrane & 64.58 & 0.47 & 0.48 & 0.69 & $<0.0001$ \\
Low mitochondrial function & 61.30 & 0.54 & 0.48 & 0.70 & $<0.0001$ \\
\hline PIA - Pecta & & & &
\end{tabular}

PIA $3 \mathrm{~h}$ - Percentage of intact acrosomes after $3 \mathrm{~h}$ of incubation at $37^{\circ} \mathrm{C}$

Damaged DNA Oh - before incubation

Damaged DNA $3 \mathrm{~h}$ - after $3 \mathrm{~h}$ of incubation at $37^{\circ} \mathrm{C}$

$\mathrm{IIH}$ - Intact acrosome, intact membrane and high mitochondrial potential

DDL - Damaged acrosome, damaged membrane and low mitochondrial potential indicating that chromatin susceptibility to acid denaturation may be greater after incubation at $37^{\circ} \mathrm{C}$, as observed in our previous study [38].

Considering the discrepancies among IVF results, individual responses in the IVF process can be assumed. In fact, the bull effect in this experiment was not prevented by pooling the semen. Grouping the bulls according to percentages of spermatozoa with PCDs (group 1/control and group 2/high levels of PCD), the rates of cleavage, blastocyst formation and hatched blastocysts did not significantly differ. A high incidence of proximal droplets is indicative of impaired epididymal maturation in young bulls and may severely compromise IVF results because when they reach sexual maturity, proximal droplets decrease and IVF potential increases [3]. However, the bulls used in the present study were adults and were sexually mature.

Considering the results from IVF of the two bulls with higher PCD levels (bulls P1 $=28.5 \%$ PCD and P2 = $40.5 \%$ PCD), P2 had a numerically lower performance in IVF, indicating that the higher levels of PCD may have affected the embryo production efficiency of this animal (P2). Thundathil et al. [7] suggested that morphologically normal sperm co-existing in the semen along with spermatozoa showing proximal droplets were also functionally deficient. These authors used semen with even higher levels of PCDs (45\% to $86 \%$ ) and found low

Table 4 Mean \pm SD percentage of spermatozoa with simultaneous intact acrosome, intact membrane and high mitochondrial potential (IIH) or damaged acrosome, damaged membrane and low mitochondrial potential (DDL) and summarised data for damaged acrosome and sperm membrane and low mitochondrial function in semen samples of group 1 (Control) and group 2 (PCD)

\begin{tabular}{lcc}
\hline \hline Spermatozoa with & Group 1 $(\mathbf{n}=\mathbf{5})$ & Group 2 ( $\mathbf{n}=\mathbf{8})$ \\
\hline IIH (\%) & $28.9 \pm 3.1$ & $17.7 \pm 5.3^{*}$ \\
DDL (\%) & $48.4 \pm 8.4$ & $64.5 \pm 9.2^{*}$ \\
Damaged acrosome (\%) & $61.5 \pm 3.2$ & $70.3 \pm 7.8^{*}$ \\
Damaged sperm membrane (\%) & $61.8 \pm 3.2$ & $78.5 \pm 5.3^{*}$ \\
Low mitochondrial function (\%) & $58.1 \pm 3.8$ & $76.7 \pm 5.4^{*}$ \\
\hline
\end{tabular}

*P $<0.05$

$\mathrm{IIH}$ - Intact acrosome, intact membrane and high mitochondrial potential DDL - Damaged acrosome, damaged membrane and low mitochondrial potential 
Table 5 Mean \pm SD rates of cleavage, blastocyst formation (BL) and hatched blastocyst per cleavage rate (BLH/CV) for group 1 (control) and group 2 (spermatozoa with increased percentages of cytoplasmic droplets PCD)

\begin{tabular}{lcccc}
\hline \hline & $\begin{array}{c}\text { Oocyte } \\
(\mathbf{n})\end{array}$ & $\begin{array}{c}\text { Cleavage } \\
(\%)\end{array}$ & $\begin{array}{c}\text { Blastocyst } \\
(\%)\end{array}$ & $\begin{array}{c}\text { Hatched BL (HBL/ } \\
\text { CV-\%) }\end{array}$ \\
\hline $\begin{array}{l}\text { Group } \\
\mathbf{1}\end{array}$ & 558 & $63.6 \pm 15.4$ & $33.4 \pm 15.7$ & $13.4 \pm 10.0$ \\
$\begin{array}{l}\text { Group } \\
\quad\end{array}$ & 505 & $60.3 \pm 22.2$ & $29.8 \pm 14.2$ & $8.9 \pm 10.3$ \\
$\quad(P>0.05)$ & & & & \\
\hline
\end{tabular}

cleavage rates (8\% to $15 \%)$ and no blastocyst formation. Nevertheless, the results for control bull C2 were similar to those for the high PCD bull, P2, and this result indicates that, despite our hypothesis regarding the influence of PCDs on IVF rates, the results may have been affected by different variables, such as individual bull characteristics. Bull effects on sperm motility [39], IVF results and embryo development rates have been observed in a number of investigations [19,40-44]. Both fertilising ability and competency for embryonic development have varied significantly among the semen of individual bulls [41]. Individual semen characteristics were found not to affect cleavage but to affect embryo development [40].

Our results emphasise the importance of the genetic background of individual semen donors for successful IVF procedures, as well as careful semen evaluation.

\section{Conclusions}

This study indicated that higher levels of PCDs could influence the sperm quality traits; nevertheless, this

Table 6 Mean \pm SD percentage of spermatozoa with proximal cytoplasmic droplets (PCDs), number of oocytes, cleavage, blastocyst formation (BL) and hatched blastocyst per cleavage rate (HBL/CV) for bulls C1, C2 and C3 from group 1 (control) and for bulls P1 and P2 with increased PCD (group 2)

\begin{tabular}{|c|c|c|c|c|c|}
\hline Bull & $\begin{array}{l}\text { PCD } \\
(\%)\end{array}$ & $\begin{array}{l}\text { Oocyte } \\
\text { (n) }\end{array}$ & $\begin{array}{c}\text { Cleavage } \\
(\%)\end{array}$ & $\begin{array}{c}\text { Blastocyst } \\
(\%)\end{array}$ & $\begin{array}{c}\text { Hatch BL (HBL/ } \\
\text { CV-\%) }\end{array}$ \\
\hline C1 & 0.0 & 201 & $71.5 \pm \frac{13.8}{a}$ & $37.4 \pm \frac{15.2}{a}$ & $18.0 \pm 9.7^{a}$ \\
\hline C2 & 0.0 & 138 & $57.0 \pm \frac{\mathrm{ab}}{\mathrm{b}} 18.2$ & $19.8 \pm 8.2^{b}$ & $2.5 \pm 3.6^{b}$ \\
\hline C3 & 0.0 & 219 & $59.4 \pm \frac{ \pm}{a b} 13.5$ & $39.5 \pm \frac{16.1}{a}$ & $16.5 \pm 7.9^{a}$ \\
\hline P1 & 28.5 & 210 & $\begin{array}{c}72.0 \pm 17.3 \\
a\end{array}$ & $39.6 \pm \frac{11.3}{a}$ & $16.1 \pm 11.1^{\mathrm{a}}$ \\
\hline P2 & 40.5 & 295 & $50.2 \pm 21.8$ & $21.3 \frac{ \pm}{b} 10.8$ & $2.7 \pm 3.5^{b}$ \\
\hline
\end{tabular}

Means with different superscripts in the same column differ significantly $(P<0.05)$. effect was not sufficient to impair motility and vigour, but it did affect the integrity of the acrosomal membrane and plasma membrane and resulted in low mitochondrial potential after thawing. Chromatin was not affected overall by higher levels of PCDs, but it showed a greater correlation with damage, especially after $3 \mathrm{~h}$ of incubation at $37^{\circ} \mathrm{C}$. As previously stated, IVF and embryo production results may have been affected by the interaction of morphology traits and individual bull effects.

\section{Acknowledgements and funding}

This work received financial support from FAPESP - 2006/03537-1. The authors thank Professor Rubens Paes de Arruda, who collaborated on the triple staining technique for semen analysis.

\section{Author details}

'Univ Estadual Paulista (UNESP), FMVA, Faculty of Veterinary Medicine, Department of Clinics, Surgery and Animal Reproduction, Araçatuba, Brazil. ${ }^{2}$ Univ Estadual Paulista (UNESP), Department of Support, Production and Animal Health, Araçatuba, Brazil. ${ }^{3}$ CRVLagoa, Sertãozinho, Brazil.

\section{Authors' contributions}

JTC carried out the semen evaluation and IVF procedures and wrote the manuscript; GZM coordinated the IVF procedure; LHR and CR participated in semen collection, freezing and evaluation; SHVP performed the statistical analyses; and MBK was the organiser and the principal investigator. All the authors have read and approved the final manuscript.

\section{Competing interests}

The authors declare that they have no competing interests.

Received: 27 June 2011 Accepted: 12 January 2012

Published: 12 January 2012

\section{References}

1. Aitken RJ, Krausz C: Oxidative stress, DNA damage and the $Y$ chromosome. Reproduction 2001, 122:497-506.

2. Liu DY, Baker HWG: Evaluation and assessment of semen for IVF/ICSI. AJA 2002, 4:281-285

3. Amann RP, Seidel GE, Mortimer RG: Fertilizing potential in vitro of semen from young beef bulls containing a high or low percentage of sperm with a proximal droplet. Theriogenology 2000, 54:1499-1515.

4. Gergely A, Kovanci E, Senturk L, Cosmi E, Vigue L, Huszar G: Morphometric assessment of mature and diminished -maturity human spermatozoa: sperm regions that reflect differences in maturity. Hum Reprod 1999, 14:2007-2014.

5. Amann RP: Tests to measure the quality of spermatozoa at spermiation. AJA 2010, 12:71-78.

6. Chacón J: Assessment of sperm morphology in zebu bulls, under field conditions in the conditions in the tropics. Reprod Domest Anim 2001, 36:91-99.

7. Thundathil J, Palasz AT, Barth AD, Mapletoft RJ: The use of in vitro fertilization techniques to investigate the fertilizing ability of bovine sperm with proximal cytoplasmic droplets. Theriogenology 2001, 65:181-192.

8. Celeghini ECC, Arruda RP, Andrade AFC, Raphael CF, Nascimento J: Simultaneous evaluation of the plasmatic, acrosomal and mitochondrial membranes in equine spermatozoa. Proceedings of Fifteen International Congress on Animal Reproduction, Porto Seguro 2004, 511.

9. Benchaib M, Braun V, Lornage J, Hadj S, Salle B, Lejeune H, Guerin JF: Sperm DNA fragmentation decreases pregnancy rate in an assisted reproductive technique. Hum Reprod 2003, 18:1023-1028.

10. Colenbrander B, Gadella BM, Stout TA: The predictive value of semen analysis in the evaluation of stallion fertility. Reprod Domest Anim 2003, 38:305-311. 
11. Blom E: Ultrastructure of some characteristic sperm defects and a proposal for a new classification of the bull spermiogram. Nordisk Veterinaer Medicin 1973, 25:383-391.

12. Barth AD, Oko RJ: Abnormal morphology of bovine spermatozoa Ames: Iowa University Press; 1989, 285.

13. Saacke RG, White JM: Semen quality tests and their relationship to fertility 1972, 22, Proc. 4 th Tech Conf Artif Insem Reprod NAAB.

14. Tejada Rl, Mitchell JC, Norman A, Marik JJ, Friedman SA: Test for the practical evaluation of male fertility by acridine orange (AO) fluorescence. Fertil Steril 1984, 42:87-91.

15. Unanian MM: Integridade da cromatina: método complementar para avaliação da qualidade do sêmen bovino Brasília: Embrapa Recursos Genéticos e Biotecnologia; 2000, 21.

16. Khalifa TAA, Rekkas CA, Lymberopoulos AG, Sioga A, Dimitriadis I, Papanikolaou T: Factors affecting chromatin stability of bovine spermatozoa. Anim Reprod Sci 2008, 104:143-163.

17. Celeghini ECC, Arruda RP, Andrade AFC, Nascimento J, Raphael CF: Practical Techniques for Bovine Sperm Simultaneous Fluorimetric Assessment of Plasma, Acrosomal and Mitochondrial Membranes. Reprod Domest Anim 2007, 42:479-488.

18. Gonçalves FS, Baretto LSS, Arruda RP, Perri SHV, Mingoti GZ: Effect of Antioxidants During Bovine In Vitro Fertilization Procedures on Spermatozoa and Embryo Development. Reprod Domest Anim 2008, 9:1-7.

19. Parrish JJ, Parrish JL, First NL: Bovine in vitro insemination with thawed semen. Theriogenology 1986, 25:591-600.

20. Mingoti GZ, Castro VSDC, Méo SC, Barretto LSS, Garcia JM: The effect of interaction between macromolecule supplement and oxygen tension on bovine oocytes and embryos cultured in vitro. Zygote 2009, 17:321-328.

21. Barretto LSS, Castro VSDC, Garcia JM, Mingoti GZ: Meiotic inhibition of bovine oocytes in medium supplemented with a serum replacer and hormones: effects on meiosis progression and developmental capacity. Zygote 2010, 19:107-116.

22. Mingoti GZ, Castro VSDC, Méo SC, Barretto LSS, Garcia JM: The effects of macromolecular and serum supplements and oxygen tension during bovine in vitro procedures on kinetics of oocyte maturation and embryo development. In Vitro Cellular \& Developmental Biology - Animal 2011, 47:361-367.

23. Vajta G, Rindom N, Peura TT, Holm P, Greve T, Callesen H: The effect of media, serum and temperature on in vitro survival of bovine blastocysts after open pulled straw (OPS) vitrification. Theriogenology 1999, 52:939-948.

24. Zar JH: Biostatistical analysis. 4 edition. New Jersey: Prentice-Hall; 1999, 663.

25. Zini A, O'Bryan MK, Israel L, Schlegel PN: Human sperm NADH and NADPH diaphorasecytochemistry: correlation with sperm motility. Urology 1998, 51:464-468.

26. Lunstra DD, Echternkamp SE: Puberty in Beef Bulls: Acrosome Morphology and Semen Quality in Bulls of Different Breeds. J Anim Sci 1982, 55:638-648.

27. Cooper TG: The epididymis, cytoplasmic droplets and male fertility. AJA 2011, 13:130-138.

28. Said TM, Agarwal A, Sharma RK: Impact of sperm morphology on DNA damage caused by oxidative stress induced by nicotinamide adenine dinucleotide phosphate. Fertil Steril 2005, 83:95-103.

29. Aitken RJ, Wingate JK, De Iuliis GN, McLaughlin EA: Analysis of lipid peroxidation in human spermatozoa using BODIPY C11. Mol Hum Reprod 2007, 13:203-211.

30. Brouwers JFHM, Gadella BM: In situ detection and localization of lipid peroxidation in individual bovine sperm cells. J Free Rad Bio Med 2003, 11:1382-1391.

31. Watson PF: Recent developments and concepts in the cryopreservation of spermatozoa and the assessment of their post-thawing function. Reprod Fertil Dev 1995, 7:871-891.

32. Correa JR, Pace MM, Zavos PM: Relationships among frozen-thawed sperm characteristics accessed via the routine semen analysis, sperm functional tests and fertility of bulls in an artificial insemination program. Theriogenology 1997, 48:721-731.

33. O'Connell M, McClure M, Lewis SE: The effects of cryopreservation on sperm morphology, motility and mitochondrial function. Hum Reprod 2002, 17:704-709.

34. Nagy S, Jansen J, Topper EK, Gadella B: A Triple-Stain Flow Cytometric Method to Assess Plasma- and Acrosome-Membrane Integrity of
Cryopreserved Bovine Sperm Immediately after Thawing in Presence of Egg-Yolk Particles. Biol Reprod 2003, 68:1828-1835.

35. Arruda RP, Celeghini ECC: Validação de técnica para avaliação simultânea das membranas plasmática, acrossomal e mitocondrial de espermatozoides bovinos. Acta Scient Vet 2003, 31:230-231.

36. Hallap T, Nagy SZ, Jaakma U, Johannisson A, Rodriguez-Martinez H: Mitochondrial activity of frozen-thawed spermatozoa assessed by MitoTracker Deep Red 633. Theriogenology 2005, 63:2311-2322.

37. Casey PJ, Hillman RB, Robertson KR, Yudin Al, Liu IKM, Drobnis EZ: Validation of an acrosomal stain for equine sperm that differentiates between living and dead sperm. Journal of Andrology 1993, 14:289-297.

38. Carreira JT, Koivisto MB, Mingoti GZ, Perri SHV: Correlation between DNA integrity and high levels of proximal cytoplasmatic droplets in bovine spermatozoa. Proceedings of the International Symposium on Animal Biology of Reproduction, 2006, Belo Horizonte. Anim Reprod 2006, 3:242.

39. Davis AP, Foote RH: Relationship of sire fertility to acrosome-reacted and motile spermatozoa after treatment with liposomes. J Dairy Sci 1987, 70:850-857.

40. Eyestone $\mathrm{WH}$, First $\mathrm{NL}$ : Variation in bovine embryo development in vitro due to bulls. Theriogenology 1989, 31:191, (Abstract).

41. Larocca C, Romano JE, Calvo J, Lago I, Fila D, Roses G, Viqueira M, Kmaid S, Imai K: Relation between Bulls and Semen Preparation on In Vitro Produced Bovine Embryos. J Mamm Ova Res 1997, 14:139-142.

42. Coelho LA, Esper CR, Garcia JM, Vantini R, Silva-Filho IR, Almeida IL Jr: Evaluation of oocyte maturation conditions and bull effect on the in vitro bovine embryo production. Braz J Vet Res Anim Sci 1998, 35:120-122.

43. Walters AH, Eyestone WE, Saacke RG, Pearson RE, Gwazdauskas FC: Bovine embryo development after IVF with spermatozoa having abnormal morphology. Theriogenology 2005, 63:1925-1937.

44. Jamil H, Samad HA, Qureshi Zl, Rehman N, Lodhi LA: Effect of bull and sperm preparation method on in vitro fertilization of buffalo oocytes. Pakistan Vet J 2007, 27:29-34.

doi:10.1186/1751-0147-54-1

Cite this article as: Carreira et al.: Impact of proximal cytoplasmic droplets on quality traits and in-vitro embryo production efficiency of cryopreserved bull spermatozoa. Acta Veterinaria Scandinavica 2012 54:1.

\section{Submit your next manuscript to BioMed Central and take full advantage of:}

- Convenient online submission

- Thorough peer review

- No space constraints or color figure charges

- Immediate publication on acceptance

- Inclusion in PubMed, CAS, Scopus and Google Scholar

- Research which is freely available for redistribution

Submit your manuscript at www.biomedcentral.com/submit
C Biomed Central 